\title{
Long-term individual and population functional outcomes in older adults with atrial fibrillation
}

Anna L. Parks, MD (1), Sun Y. Jeon, MS PhD (2), W. John Boscardin, PhD (2, 4), Michael A. Steinman, MD (2), Alexander K. Smith, MD, MPH, MAS (2), Margaret C. Fang, MD, MPH (3), Sachin J. Shah, MD, MPH (3)

(1) Division of Hematology and Oncology, University of California, San Francisco, San Francisco, CA

(2) Division of Geriatrics, University of California, San Francisco and San Francisco VA Medical Center, San Francisco, CA

(3) Division of Hospital Medicine, University of California, San Francisco, San Francisco, CA

(4) Department of Epidemiology and Biostatistics, University of California, San Francisco, San Francisco, CA

Corresponding Author

Anna Parks, MD

19 Division of Hematology

20 University of California, San Francisco,

21505 Parnassus Ave., San Francisco, CA 94143

22 E-mail: Anna.Parks@ucsf.edu;

23 Phone: (801) 209-3969;

24 Fax: (415) 514-2094

Running title: Parks - Stroke and Long-term function in AF

Main text word count: 2977

Impact statement: We certify that this work is novel. Little is known about long-term function (ADL, IADL, community-dwelling) among older adults with AF and the association with stroke.

34 This nationally representative study finds a high rate of function loss independent of stroke, and 35 among those who suffer a stroke, a dramatic and immediate decline in function. Because of the 36 high rate of function loss independent of stroke and the relatively low rate of stroke, on a 37 population level, stroke is not the dominant determinant of disability in older adults with AF. 


\section{Abstract $(297 / 300)$}

40 Background: Older adults with atrial fibrillation (AF) have multiple risk factors for disablement.

41 Long-term function and the contribution of strokes to disability has not been previously

42 characterized.

43 Methods: We performed a longitudinal, observational study in the nationally representative

44 Health and Retirement Study (1992-2014). We included participants $\geq 65$ years with Medicare

45 claims who met incident AF diagnosis claims criteria. We examined the association of incident

46 stroke with three functional outcomes: independence with activities of daily living (ADL) and

47 instrumental activities of daily living (IADL) and community-dwelling. We fit separate logistic

48 regression models with repeated measures adjusting for comorbidities and demographics to

49 estimate the effect of stroke on function. We estimate the contribution of strokes to the overall

50 population burden of functional impairment using the method of recycled predictions.

51 Results: Among 3530 participants (median age 79 years, 53\% women, median $\mathrm{CHA}_{2} \mathrm{DS}_{2}-\mathrm{VASc}$

52 5), 262 had a stroke over 17,396 person-years. Independent of stroke and accounting for

53 population comorbidities, annually, ADL dependence increased by $4.4 \%$, IADL dependence

54 increased by $3.9 \%$, and nursing home residence increased by $1.2 \%(p<0.05$ for all). Accounting

55 for comorbidities, of those who experienced a stroke, 31.9\% developed new ADL dependence,

$5626.5 \%$ developed new IADL dependence, and $8.6 \%$ newly moved to a nursing home $(p<0.05$ for

57 all). Considering all causes of function loss, $1.7 \%$ of ADL disability-years, $1.2 \%$ of IADL

58 disability-years, and $7.3 \%$ of nursing home years could be attributed to stroke over 7.4years.

59 Conclusion: Older adults lose substantial function over time following AF diagnosis,

60 independent of stroke. Stroke was associated with a significant decline in function and an

61 increase in the likelihood of nursing home move, but stroke did not accelerate subsequent

62 disability accrual. Because of the high background rate of functional loss, stroke was not the

63 dominant determinant of population-level disability in older adults with AF. 


\section{Introduction}

Atrial fibrillation (AF) is a significant health burden for older adults, affecting 1 in 25 of those over age 60 and 1 in 10 over age $80 .{ }^{1}$ Stroke is the most dreaded consequence of AF for older adults, who often equate stroke with abrupt and persistent loss of independence.

While prior studies have clearly demonstrated that AF-related strokes result in increased shortterm disability, long-term functional outcomes for AF patients generally, and specifically before and after stroke, remain uncharted. ${ }^{2}$ While many strokes result in sudden and life-altering disability, disability can also result from an accumulation of impairments independent of stroke.

74 Particularly in older adults, AF frequently coexists with other medical conditions that increase

75 the risk of disability. ${ }^{3,4}$ Also, while often overlooked, geriatric syndromes, such as falls and cognitive impairment, are also important contributors to loss of independence in older AF impairment, and functional impairments are common. ${ }^{7,8}$ In the absence of longitudinal data in disablement remains unclear.

82 Stroke is perceived as a dominant pathway to disability in patients with AF, yet information

83 assessing its actual population health burden is limited. Compared to the prevalence of other

84 risk factors for disability, stroke remains an uncommon occurrence even among AF patients.

85 Thus, many older adults with AF may be predisposed to disablement even in the absence of 86 stroke, but this has not been previously quantified.

88 Understanding the longitudinal course of independence of older patients with AF, and whether 89 and to what degree stroke affects their long-term trajectory, is vital to inform treatment decision90 making, advance care planning, and public health interventions. To address these gaps, we 
used a nationally representative cohort of older adults with incident AF to determine long-term

92 functional outcomes and the relative contribution of strokes.

\section{Methods}

95 Study design and participants

96 We performed a longitudinal, observational study to examine the association between incident

97 stroke and functional status in a cohort of older adults with AF. We used data from 1992-2014

98 from the Health and Retirement Study (HRS), a longitudinal, nationally representative survey of

99 more than 37,500 Americans age 50 and older, which amounts to 350,000 person-years of

100 observation. ${ }^{9}$ Subjects are interviewed every two years by phone, in person or via internet

101 surveys. The goal of the HRS is to measure changes in health, wealth, social structure, and

102 function as participants retire, with questions covering four aging-related topics: economic

103 security, mental and physical health and function, work and retirement, and social connections.

104 Proxy interviewees, typically family members, are used for those who cannot participate

105 because of physical or cognitive impairment. The HRS is linked to Medicare insurance claims

106 for participants who consent. ${ }^{10}$ The HRS sampling design yields a nationally representative

107 sample of community-dwelling adults and nursing home residents in the US. ${ }^{11}$

109 We identified a cohort of HRS subjects aged 65 and older with Medicare claims linkage and

110 continuous Medicare Part A and B enrollment (cohort flow diagram Appendix 1). We included

111 participants if their claims had one inpatient or two outpatient claims for AF in the first or second

112 position (427.31 from the International Classification of Diseases Ninth revision, Clinical

113 Modification). Cases were defined as incident AF if they had 12 months of continuous

114 enrollment in Medicare Part A and B with no prior AF claims diagnosis. ${ }^{12}$ To ensure accurate

115 information about participants' baseline characteristics, we excluded those whose first interview

116 occurred more than 2.5 years before their AF diagnosis; a timeframe of 2.5 years was selected 
117 because of the variable biennial timing between HRS interviews. ${ }^{13}$ To obtain longitudinal

118 outcome and exposure information, we excluded participants who had no interviews after a

119 diagnosis of AF. Participants were censored at the time of disenrollment from Medicare part A

120 or B, HRS drop out, or death, whichever came first.

Measures: Demographics and comorbidities

123 We used HRS interview data to characterize participants' age, gender, education level, race,

124 ethnicity, education, marital status, and whether they lived alone. We report information on

125 comorbid conditions that affect stroke risk, including congestive heart failure, hypertension, prior

126 stroke, diabetes mellitus, prior myocardial infarction or angina, or cancer (excluding skin

127 cancer). We characterized patients as having a specific clinical comorbidity if (1) they report a

128 physician had ever told them they had a specific condition or (2) they met Medicare claims

129 criteria (definitions found in Appendix 2). Prior studies have examined the validity of self-

130 reported cardiovascular comorbidities, such as those used in the $\mathrm{CHA}_{2} \mathrm{DS}_{2}$-VASc score, finding

131 self-reported diagnoses to reflect medical charts and population-level estimates accurately. ${ }^{14-16}$

132 Clinical characteristics were used to compute a $\mathrm{CHA}_{2} \mathrm{DS}_{2}-\mathrm{VASc}$ (Congestive heart failure,

133 Hypertension, Age, Diabetes mellitus, Stroke, Vascular disease, and Sex) score to estimate the

134 risk of ischemic stroke. ${ }^{17}$ We report participants' baseline demographic and comorbidity

135 information from the most recent interview before their AF diagnosis.

\section{Measures: Stroke}

138 We used a claims-based definition of ischemic (ICD-9 codes: 434.x and 436.x; ICD10: I63.x)

139 and hemorrhagic stroke (ICD9: 430.x and 431.x; ICD10: I61.x). ${ }^{18}$ To classify incident stroke

140 events, we identified subjects with an inpatient admission with a primary diagnosis code for

141 ischemic or hemorrhagic stroke. We examined the first stroke after AF diagnosis for each

142 participant in the analysis. 
medRxiv preprint doi: https://doi.org/10.1101/2020.11.05.20223297; this version posted November 6, 2020. The copyright holder for this preprint (which was not certified by peer review) is the author/funder, who has granted medRxiv a license to display the preprint in perpetuity.

All rights reserved. No reuse allowed without permission.

\section{Outcomes: Function}

144 We measured the effect of strokes on three functional outcomes: activities of daily living (ADL)

145 impairment, instrumental activities of daily living (IADL) impairment, and community dwelling.

146 We defined ADL dependence as a respondent stating that they required help with any of 6

147 ADLs (walking, dressing, bathing, eating, transferring to or from bed, and toileting). We defined

148 IADL dependence as a respondent stating that they required assistance with any of 5 IADLs

149 (preparing a hot meal, shopping for groceries, making telephone calls, taking medicines, and

150 managing money). We defined nursing home move as spending $\geq 90$ nights in a nursing home

151 since the last interview. We defined the outcome of community-dwelling as no nursing home

152 move since the last interview. All three functional outcomes were measured at each interview.

154 Analysis

155 We measured the prevalence of cohort demographics and comorbidities at the time of AF 156 diagnosis. To determine the association between stroke and each functional outcome, we fit 157 separate random-effects logistic regression models with repeated measures. We modeled the 158 effect of stroke on function by including an interaction term between stroke and time since AF 159 diagnosis (modeling equation in Appendix 3). In each model, we adjusted for covariates, 160 defined a priori, that contribute to stroke and disability: age, sex, congestive heart failure, 161 hypertension, prior stroke, diabetes mellitus, prior myocardial infarction or angina, or history of 162 cancer (excluding skin cancer). We determined the log-odds for each outcome: ADL

163 dependence, IADL dependence, and nursing home residence. To visually illustrate the effect of

164 stroke on the probability of ADL independence, IADL independence, and nursing home

165 residence, we present the predicted population rates and the average marginal effects. ${ }^{19}$ We did 166 not use significance testing to determine which confounders to include in the regression models, 167 consistent with epidemiologic best practices..$^{19}$ If, during an otherwise completed interview, ADL, 168 IADL, nursing home status were not obtained, the participant was not included in the analysis 
for that outcome in that time period ( $<4 \%$ of interviews). A substantial proportion of missing

170 interviews were exit interviews with next-of-kin (1.5\% of all interviews). When an exit interview

171 was completed, next-of-kin reported ADL and IADL dependence $>90 \%$ of the time. As such,

172 when exit interviews were missing, we imputed ADL and IADL status as dependent.

174 To estimate the contribution of strokes to the overall population burden of functional impairment 175 in patients with $\mathrm{AF}$, we used the method of recycled predictions. ${ }^{20,21}$ First, using the regression

176 model results (Appendix 4) and the observed stroke rate, we estimated the burden of

177 dependence for the population that had a stroke and the population that did not have a stroke 178 projected over 7.4 (measured in disability-years). We chose 7.4 years because it was the $75^{\text {th }}$

179 percentile of follow-up time. Next, we used the same parameters to estimate the disability-years

180 for the same population assuming no strokes had occurred. The difference between the two

181 measures of disability-years represents the disability-years attributable to stroke (detailed

182 methods and visual description presented in Appendix 5).

184 We performed all analyses using SAS 9.4 (Cary, NC) and STATA (Version 16.1, College

185 Station, TX). We report all results with 95\% confidence intervals. STROBE statement checklist 186 can be found in Appendix 6.

\section{Results}

189 Cohort characteristics

190 We included 3,530 participants in our analysis with an average of 4.9 years of follow-up time, 191 amounting to 17,396 person-years of observation. At the time of AF diagnosis, the median age 192 was 79 years, $53 \%$ were women, $85 \%$ identified as white, $9.0 \%$ as Black, and $10.0 \%$ were 193 proxy interviews (Table). The most common comorbid condition among participants was 194 hypertension (79\%), followed by prior myocardial infarction or angina (58\%), congestive heart 
195 failure (36\%), diabetes (31\%), prior stroke (23\%), and cancer (22\%). The median $\mathrm{CHA}_{2} \mathrm{DS}_{2^{-}}$

196 VASc score in the cohort was 5 (IQR 4, 7). During the follow-up period after AF diagnosis, 262

197 participants, or $7.4 \%$, had a stroke (1.5 strokes per 100 person-years). The median time from

198 AF diagnosis to stroke was 2.8 years (IQR $0.8,6.0$ ).

199

200 Longitudinal functional outcomes

201 Figure 1 graphically represents three key findings for each of the three functional outcomes-

202 the baseline rate of lost function independent of stroke, the immediate loss of function following

203 stroke, and change in the baseline rate of lost function following stroke. We present the full

204 model results, including unadjusted results in Appendix 4.

205

206 Independent of stroke and accounting for comorbidities, the absolute likelihood of ADL

207 independence decreased by $4.4 \%$ per year (average marginal effect [AME], $95 \% \mathrm{Cl} 4.0$ to $4.8 \%$

208 per year) (Figure 1A). Assuming a stroke at 2.8 years, the median time to stroke in this cohort,

209 stroke was associated with a decrease in the predicted likelihood of independence from 58\%

210 (pre-stroke) to 27\% (post-stroke) (AME -32\%, 95\% CI -25 to -39\%). Stroke, however, was not

211 associated with a change in the baseline rate of decline in ADL independence; that is, the

212 relative rate of $A D L$ decline post-stroke did not differ when compared to those without stroke.

214 Similar to ADL independence, independent of stroke and accounting for comorbidities, the

215 absolute likelihood of IADL independence decreased by $3.9 \%$ per year (AME, $95 \% \mathrm{CI} 3.5$ to

$2164.3 \%$ per year) (Figure 1B). Assuming a stroke at 2.8 years, stroke was associated with a

217 decrease in the predicted likelihood of IADL independence from $52 \%$ to $26 \%$ (AME -27\%, 95\%

$218 \mathrm{Cl}-20$ to $-33 \%)$. Stroke was not associated with a change in the baseline annual rate of decline 219 in IADL independence. 
221 Finally, for community-dwelling, independent of stroke and accounting for comorbidities, the

222 absolute likelihood of community-dwelling decreased by $1.2 \%$ per year (AME, $95 \% \mathrm{Cl} 1.0$ to

$2231.4 \%$ per year) (Figure 1C). Assuming a stroke at 2.8 years, stroke was associated with a

224 decrease in the predicted likelihood of community-dwelling from 94\% to 85\% (AME -8.6\%; 95\%

$225 \mathrm{Cl}-3.7$ to $-13.5 \%)$. Stroke was not associated with a change in the baseline annual rate of

226 decline in community-dwelling.

228 Population-level outcomes

229 Projected over 7.4 years, stroke accounted for a modest proportion of dependent-years among

230 older adults with AF (Figure 2). Stroke accounted for $1.7 \%(95 \% \mathrm{Cl} 1.3$ to $2.1 \%)$ of the

231 population burden of ADL disability (for 100 person-years, 46.4 dependent-years given

232 observed stroke rate vs. 45.6 disability-years assuming no strokes; attributable burden 0.8

233 disability-years/100 person-years or 1.7\%). For IADL impairment, $1.2 \%(95 \% \mathrm{Cl} 0.9$ to $1.6 \%)$ of

234 the population burden of IADL disability could be attributed to stroke (for 100 person years, 51.8

235 dependent-years given observed stroke rate vs. 51.1 dependent-years assuming no strokes;

236 attributable burden 0.6 dependent-years/100 person-years or $1.2 \%)$. For loss of community-

237 dwelling, $7.3 \%(95 \% \mathrm{Cl} 4.0$ to $10.5 \%)$ of the population burden of nursing home years could be

238 attributed to stroke (for 100 person-years, 7.7 nursing home-years given observed stroke rate

239 vs. 7.2 nursing home-years assuming no strokes; attributable burden 0.6 nursing home-

240 years/100 person-years or $7.3 \%)$.

242 Discussion

243 In this nationally representative cohort, we determined that older adults with AF experience a

244 significant loss of function over time. First, following AF diagnosis and independent of stroke, we

245 found a high rate of loss of function and nursing home moves-annual increases of $4.4 \%$ in

246 ADL dependence, 3.9\% increase in IADL dependence, and 1.2\% annual increase in nursing 
247 home residence. Second, stroke was associated with an immediate and substantial decline in

248 function and an increase in the likelihood of nursing home move. In the years following a stroke,

249 stroke survivors and those who did not experience a stroke accrued disability at similar rates;

250 that is, the loss of independence did not accelerate following stroke.

252 Contrary to prevailing wisdom, we found stroke was not the dominant determinant of disability in 253 older adults with AF on a population level. While a stroke results in striking loss of function for

254 the 1 in 13 that suffer a stroke, we found the high background rate of function loss independent 255 of stroke is the predominant pathway for population disability. In this AF cohort, projected over 256 seven years, stroke accounted for $1.7 \%$ of ADL disability-years, $1.2 \%$ of IADL disability-years, 257 and $7.3 \%$ of total time in nursing homes. Although AF-related stroke causes substantial, sudden 258 loss of function for individuals and represents a substantial public health burden, most AF 259 patients become disabled through other means.

261 These findings add to limited literature describing long-term functional outcomes among older 262 adults with AF. Two recent studies have compared the risk of disability among AF patients 263 versus those without AF. Marzona et al. showed that incident AF was associated with increased 264 loss of ADL independence, as well as rates of admission to long-term care facilities, compared 265 to those without AF.22 These associations were independent of stroke. However, because this 266 study drew from patients enrolled in randomized controlled trials, with mean age a decade 267 younger than in the current study, its results may be less generalizable to the older AF 268 population. In a cohort of adults over age 65, Wallace et al. demonstrated that, even after 269 adjusting for incident stroke or heart failure, incident AF was associated with $50 \%$ shorter 270 disability-free survival and $24 \%$ higher risk of ADL disability than those without AF. ${ }^{23}$

272 The results of this study make clear that older adults with AF acquire disabilities through 
273 multiple mechanisms. Thus, mitigating disability may require distinct interventions. To

274 ameliorate stroke-related disability, optimizing anticoagulant use and left atrial closure devices

275 continues to be a primary concern. ${ }^{24,25}$ While this study demonstrates the importance of stroke-

276 independent disability, the causes of stroke-independent disability are not well defined. Some

277 have postulated a direct link between the dysrhythmia itself and function independent of stroke.

278 For example, alterations in cardiac structure resulting from AF impair cardiac output could

279 reduce patients' capacity for both cognitive and physical activities. ${ }^{26}$ In addition to clinically

280 diagnosed stroke, AF has also been associated with subclinical ischemic events and resultant

281 disability. ${ }^{27,28}$ In this scenario, strategies could target preventing the development of atrial

282 fibrillation altogether or preventing its cardiac remodeling effects. Rather than a causal

connection between AF and disability, AF may instead be a marker for multimorbidity, frailty,

and other geriatric syndromes that predispose to impairment. In this model, novel geriatric care

models that address functional impairment using multifaceted interventions may hold promise. ${ }^{29}$

In either circumstance, when counseling patients and families regarding a diagnosis of AF, our

results should prompt a discussion of the risk of functional dependence in the years following

diagnosis of AF that is only partially mitigated by stroke prevention.

Our study has several limitations that should be considered when interpreting the results. We

291 relied on self-report for functional status measures, which are subject to recall bias, as subjects

292 may be reluctant to acknowledge these limitations or may not recall them due to cognitive

293 deficits. We excluded participants who lacked follow-up data, which could have preferentially

294 excluded those with more significant functional impairments who had difficulty completing

295 follow-up interviews. However, both limitations would likely result in underestimating the true

296 burden of disability and bias our results toward the null. The HRS assesses functional status

297 every two years, but functional deficits can develop rapidly, as such important changes could be

298 missed with this interval. Also, several studies have shown that older adults can have periods of 
299 decline and recovery, but our data did not allow for this degree of granularity. ${ }^{30}$ Nevertheless,

300 although older adults often recover from initial disability, an episode of disability is a strong

301 predictor of chronic impairment, so the overarching trajectory of function illustrated in our cohort

302 remains informative. ${ }^{31}$ Participants with the most severe or deadly strokes may be differentially

303 censored. To mitigate this bias, we assumed that all participants who died and were missing

304 outcome data were disabled before death. In a sensitivity analysis, we examined if there was a

305 differential loss to follow-up following a stroke. We did not find a significant association between

306 stroke and differential loss to follow-up (Appendix 7); this reduces the likelihood but does not

307 eliminate this potential bias. Finally, Medicare Part D prescription data are only available from

3082006 onward. Stroke severity and short-term disability are both reduced by receipt of

309 anticoagulant or antithrombotic medications, so this represents an important unmeasured

310 confounder in our results that should be evaluated in future studies. ${ }^{32}$

312 In conclusion, we found that long-term functional decline was common in older adults with AF

313 and mostly occurred in the absence of stroke. After seven years, one-third of AF patients had

314 ADL disability, one-half IADL disability, and one-tenth lived in a nursing home. Considering the

315 public health implications of AF in older adults, our results demonstrate that although stroke

316 represents a significant cause of functional decline, most disability results from other causes.

317 These results challenge the traditional thinking that the long-term function of AF patients

318 depends principally on stroke prevention. Taken together, our findings emphasize the need to

319 supplement stroke prevention along with multifaceted interventions to prevent dependence. 


\section{Acknowledgments}

Contributors: ALP, SYJ, WJB, and SJS, were responsible for the study concept and design. ALP, MAS, AKS, and SJS obtained funding and supervised the study. All authors were involved in the acquisition, analysis, or interpretation of the data. SJY performed the statistical analyses. ALP and SJS drafted the manuscript, and all authors critically revised it for important intellectual content. The corresponding author attests that all listed authors meet authorship criteria and that no others meeting the criteria have been omitted. ALP, SYJ, and SJS had full access to all the data in the study and are the guarantors.

Funding: This study was supported by the National Center for Advancing Translational Sciences (KL2TR001870), the National Institute on Aging (P30AG044281, K24AG068312, K24AG049057 \& T32-AG000212), and the National Heart Lung and Blood Institute (K24HL141354).

Sponsor's Role: The funders had no role in study design, data collection and analysis, decision to publish, or preparation of the manuscript.

Competing interests: All authors have completed the ICMJE uniform disclosure form at www.icmje.org/coi_disclosure.pdf (available on request from the corresponding author). MCF reports grants from $\mathrm{NIH} / \mathrm{NHLBI}$, during the conduct of the study. ALP, MAS, AKS report grants from NIH/NIA, during the conduct of the study. SJS reports grants from NIH/NCATS, during the conduct of the study. No financial relationships with any organizations that might have an interest in the submitted work in the previous three years; no other relationships or activities that could appear to have influenced the submitted work.

Ethical approval: The Human Research Protection Program Institutional Review Board at the University of California, San Francisco, approved this study (IRB\# 16-19185).

Data sharing: Researchers can apply to use the Health and Retirement Study (hrs.isr.umich.edu/) for access to the data use in this study. Code used to generate the cohort and perform the analyses can be found on github (https://github.com/sachinjshah). 
medRxiv preprint doi: https://doi.org/10.1101/2020.11.05.20223297; this version posted November 6, 2020. The copyright holder for this preprint

(which was not certified by peer review) is the author/funder, who has granted medRxiv a license to display the preprint in perpetuity.

All rights reserved. No reuse allowed without permission.

\section{References}

354

355

356

357

358

359

360

361

362

363

364

365

366

367

368

369

370

371

372

373

374

375

376

377

378

379

380

381

382

383

384

385

386

387

388

389

1. Go AS, Hylek EM, Phillips KA, et al. Prevalence of Diagnosed Atrial Fibrillation in Adults: National Implications for Rhythm Management and Stroke Prevention: the AnTicoagulation and Risk Factors In Atrial Fibrillation (ATRIA) Study. JAMA. 2001;285(18):2370-2375. doi:10.1001/jama.285.18.2370

2. Lin HJ, Wolf PA, Kelly-Hayes M, et al. Stroke severity in atrial fibrillation. The Framingham Study. Stroke. 1996;27(10):1760-1764. doi:10.1161/01.str.27.10.1760

3. Parks AL, Fang MC. Anticoagulation in Older Adults with Multimorbidity. Clin Geriatr Med. 2016;32(2):331-346. doi:10.1016/j.cger.2016.01.003

4. Stuck AE, Walthert JM, Nikolaus T, Büla CJ, Hohmann C, Beck JC. Risk factors for functional status decline in community-living elderly people: a systematic literature review. Soc Sci Med. 1999;48(4):445-469. doi:10.1016/S0277-9536(98)00370-0

5. Inouye SK, Studenski S, Tinetti ME, Kuchel GA. Geriatric Syndromes: Clinical, Research, and Policy Implications of a Core Geriatric Concept. J Am Geriatr Soc. 2007;55(5):780-791. doi:10.1111/j.1532-5415.2007.01156.x

6. Fried LP, Ferrucci L, Darer J, Williamson JD, Anderson G. Untangling the Concepts of Disability, Frailty, and Comorbidity: Implications for Improved Targeting and Care. $J$ Gerontol Ser A. 2004;59(3):M255-M263. doi:10.1093/gerona/59.3.M255

7. Mailhot T, McManus DD, Waring ME, et al. Frailty, Cognitive Impairment, and Anticoagulation Among Older Adults with Nonvalvular Atrial Fibrillation. J Am Geriatr Soc. $\mathrm{n} / \mathrm{a}(\mathrm{n} / \mathrm{a})$. doi:10.1111/jgs.16756

8. Shah SJ, Fang MC, Jeon SY, Gregorich SE, Covinsky KE. Geriatric Syndromes and Atrial Fibrillation: Prevalence and Association with Anticoagulant Use in a National Cohort of Older Americans. J Am Geriatr Soc. n/a(n/a). doi:10.1111/jgs.16822

9. Juster FT, Suzman R. An Overview of the Health and Retirement Study. J Hum Resour. 1995;30:S7-S56. doi:10.2307/146277

10. Fisher GG, Ryan LH. Overview of the Health and Retirement Study and Introduction to the Special Issue. Work Aging Retire. 2018;4(1):1-9. doi:10.1093/workar/wax032

11. Sonnega A, Faul JD, Ofstedal MB, Langa KM, Phillips JWR, Weir DR. Cohort Profile: the Health and Retirement Study (HRS). Int J Epidemiol. 2014;43(2):576-585. doi:10.1093/ije/dyu067

12. Borzecki AM, Wong AT, Hickey EC, Ash AS, Berlowitz DR. Identifying HypertensionRelated Comorbidities From Administrative Data: What's the Optimal Approach? Am J Med Qual. 2004;19(5):201-206. doi:10.1177/106286060401900504

13. Tang VL, Sudore R, Cenzer IS, et al. Rates of Recovery to Pre-Fracture Function in Older Persons with Hip Fracture: an Observational Study. J Gen Intern Med. 2017;32(2):153-158. doi:10.1007/s11606-016-3848-2 
medRxiv preprint doi: https://doi.org/10.1101/2020.11.05.20223297; this version posted November 6, 2020. The copyright holder for this preprint (which was not certified by peer review) is the author/funder, who has granted medRxiv a license to display the preprint in perpetuity. All rights reserved. No reuse allowed without permission.

390

391

392

393

394

395

396

397

398

399

400

401

402

403

404

405

406

407

408

409

410

411

412

413

414

415

416

417

418

419

420

421

422

423

424

425

426

427
14. Bush TL, Miller SR, Golden AL, Hale WE. Self-report and medical record report agreement of selected medical conditions in the elderly. Am J Public Health. 1989;79(11):1554-1556. doi:10.2105/AJPH.79.11.1554

15. Okura Y, Urban LH, Mahoney DW, Jacobsen SJ, Rodeheffer RJ. Agreement between selfreport questionnaires and medical record data was substantial for diabetes, hypertension, myocardial infarction and stroke but not for heart failure. J Clin Epidemiol. 2004;57(10):1096-1103. doi:10.1016/j.jclinepi.2004.04.005

16. Glymour MM, Avendano M. Can self-reported strokes be used to study stroke incidence and risk factors?: evidence from the health and retirement study. Stroke. 2009;40(3):873-879. doi:10.1161/STROKEAHA.108.529479

17. Lip GYH, Nieuwlaat R, Pisters R, Lane DA, Crijns HJGM. Refining Clinical Risk Stratification for Predicting Stroke and Thromboembolism in Atrial Fibrillation Using a Novel Risk FactorBased Approach: The Euro Heart Survey on Atrial Fibrillation. CHEST. 2010;137(2):263272. doi:10.1378/chest.09-1584

18. Kokotailo Rae A., Hill Michael D. Coding of Stroke and Stroke Risk Factors Using International Classification of Diseases, Revisions 9 and 10. Stroke. 2005;36(8):1776-1781. doi:10.1161/01.STR.0000174293.17959.a1

19. Inappropriate use of bivariable analysis to screen risk factors for use in multivariable analysis - PubMed. Accessed August 26, 2020. https://pubmed-ncbi-nlm-nihgov.ucsf.idm.oclc.org/8699212/

20. Bieler GS, Brown GG, Williams RL, Brogan DJ. Estimating model-adjusted risks, risk differences, and risk ratios from complex survey data. Am J Epidemiol. 2010;171(5):618623. doi:10.1093/aje/kwp440

21. Graubard BI, Korn EL. Predictive margins with survey data. Biometrics. 1999;55(2):652-659. doi:10.1111/j.0006-341x.1999.00652.x

22. Marzona I, O'Donnell M, Teo K, et al. Increased risk of cognitive and functional decline in patients with atrial fibrillation: results of the ONTARGET and TRANSCEND studies. CMAJ Can Med Assoc J. 2012;184(6):E329-E336. doi:10.1503/cmaj.111173

23. Wallace ER, Siscovick DS, Sitlani CM, et al. Incident Atrial Fibrillation and Disability-Free Survival in the Cardiovascular Health Study. J Am Geriatr Soc. 2016;64(4):838-843. doi:10.1111/jgs.14037

24. Reddy VY, Doshi SK, Kar S, et al. 5-Year Outcomes After Left Atrial Appendage Closure: From the PREVAIL and PROTECT AF Trials. J Am Coll Cardiol. 2017;70(24):2964-2975. doi:10.1016/j.jacc.2017.10.021

25. Okumura K, Akao M, Yoshida T, et al. Low-Dose Edoxaban in Very Elderly Patients with Atrial Fibrillation. N Engl J Med. 2020;0(0):null. doi:10.1056/NEJMoa2012883

26. Groenveld HF, Crijns HJGM, Van den Berg MP, et al. The Effect of Rate Control on Quality of Life in Patients With Permanent Atrial Fibrillation: Data From the RACE II (Rate Control 
medRxiv preprint doi: https://doi.org/10.1101/2020.11.05.20223297; this version posted November 6, 2020. The copyright holder for this preprint (which was not certified by peer review) is the author/funder, who has granted medRxiv a license to display the preprint in perpetuity.

All rights reserved. No reuse allowed without permission.

Efficacy in Permanent Atrial Fibrillation II) Study. J Am Coll Cardiol. 2011;58(17):1795-1803. doi:10.1016/j.jacc.2011.06.055

27. Rosano C, Kuller LH, Chung H, Arnold AM, Longstreth WT, Newman AB. Subclinical brain magnetic resonance imaging abnormalities predict physical functional decline in highfunctioning older adults. J Am Geriatr Soc. 2005;53(4):649-654. doi:10.1111/j.15325415.2005.53214.x

28. Petersen P, Madsen EB, Brun B, Pedersen F, Gyldensted C, Boysen G. Silent cerebral infarction in chronic atrial fibrillation. Stroke. 1987;18(6):1098-1100. doi:10.1161/01.STR.18.6.1098

29. Szanton SL, Leff B, Wolff JL, Roberts L, Gitlin LN. Home-Based Care Program Reduces Disability And Promotes Aging In Place. Health Aff (Millwood). 2016;35(9):1558-1563. doi:10.1377/hlthaff.2016.0140

30. Hardy SE, Gill TM. Recovery From Disability Among Community-Dwelling Older Persons. JAMA. 2004;291(13):1596-1602. doi:10.1001/jama.291.13.1596

31. Gill TM, Kurland BF. Prognostic Effect of Prior Disability Episodes among Nondisabled Community-living Older Persons. Am J Epidemiol. 2003;158(11):1090-1096. doi:10.1093/aje/kwg237

32. Jung YH, Kim YD, Kim J, et al. Initial Stroke Severity in Patients With Atrial Fibrillation According to Antithrombotic Therapy Before Ischemic Stroke. Stroke. 2020;51(9):27332741. doi:10.1161/STROKEAHA. 120.030138 
medRxiv preprint doi: https://doi.org/10.1101/2020.11.05.20223297; this version posted November 6, 2020. The copyright holder for this preprint (which was not certified by peer review) is the author/funder, who has granted medRxiv a license to display the preprint in perpetuity.

All rights reserved. No reuse allowed without permission.

449 Table: Baseline characteristics of the cohort of older adults with atrial fibrillation

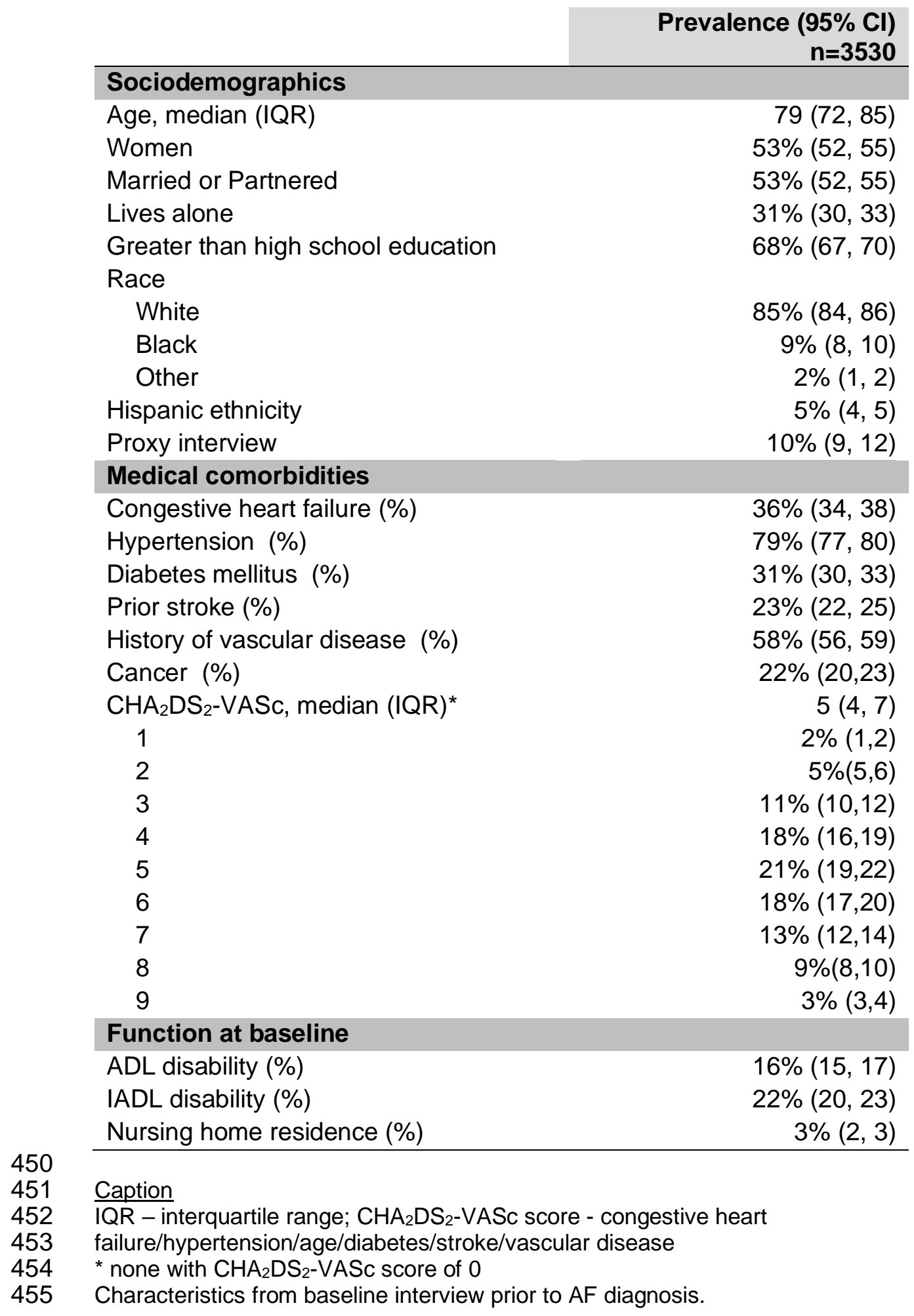


medRxiv preprint doi: https://doi.org/10.1101/2020.11.05.20223297; this version posted November 6, 2020. The copyright holder for this preprint (which was not certified by peer review) is the author/funder, who has granted medRxiv a license to display the preprint in perpetuity.

All rights reserved. No reuse allowed without permission.

Figure 1: Longitudinal likelihood of ADL independence, IADL independence, and community dwelling and association with stroke

(A) ADL independence

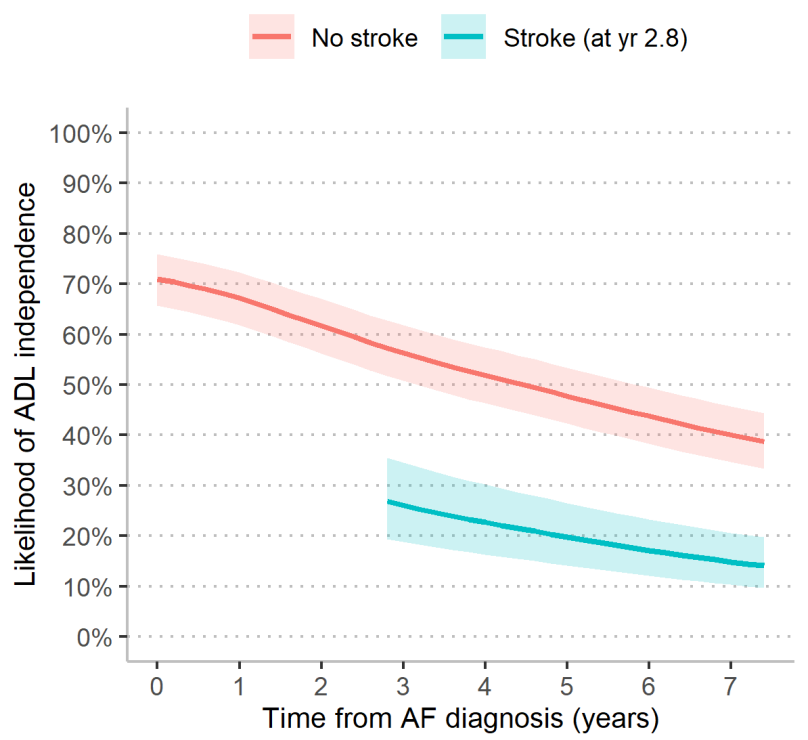

(C) Community dwelling

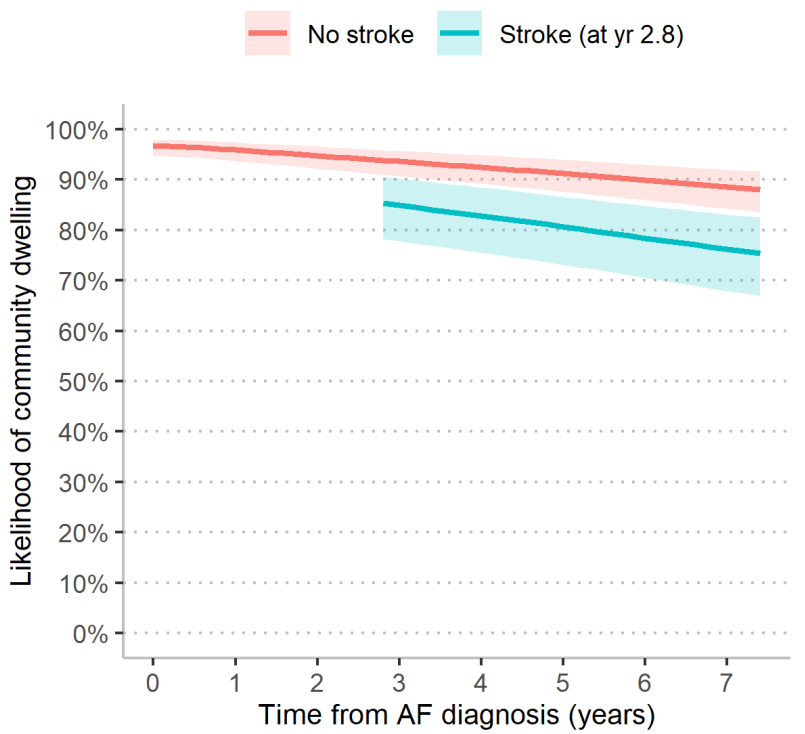

(B) IADL independence

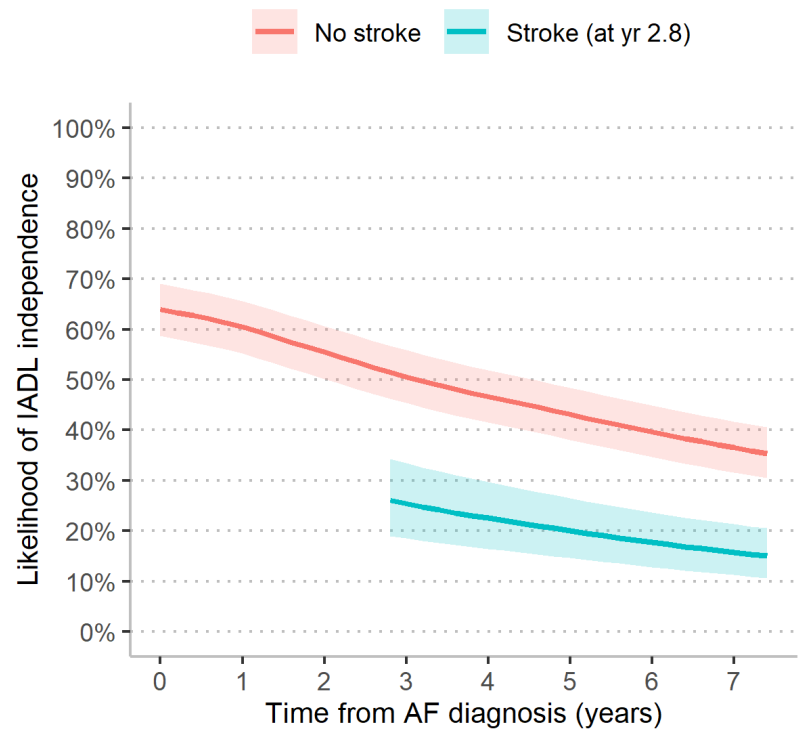

\section{Caption}

ADL - activity of daily living; IADL - instrumental activity of daily living

The slope represents the average marginal effect of a one-year change on independence, adjusting for demographics and comorbidities. The blue line represents the predicted likelihood of the outcome without stroke and the red line represents the predicted likelihood of the outcome following stroke at 2.8 years (the median time to stroke in the cohort). For the population who goes on to have a stroke, the blue line from 0 to 2.8 years represents the pre-stroke trajectory and the red line describes the post-stroke trajectory. Functional trajectory is displayed through 7.4 years, the $75^{\text {th }}$ percentile of follow up time. The analysis is based on 3530 participants; we excluded 26 person waves $(0.3 \%)$ with missing ADL outcome data, 213 person-waves (2.1\%) with missing IADL outcome data, and 368 person-waves (3.5\%) with missing nursing home outcome data. 
medRxiv preprint doi: https://doi.org/10.1101/2020.11.05.20223297; this version posted November 6, 2020. The copyright holder for this preprint (which was not certified by peer review) is the author/funder, who has granted medRxiv a license to display the preprint in perpetuity.

471 Figure 2: Contribution of strokes to population ADL independence, IADL independence, and

(A) ADL independence

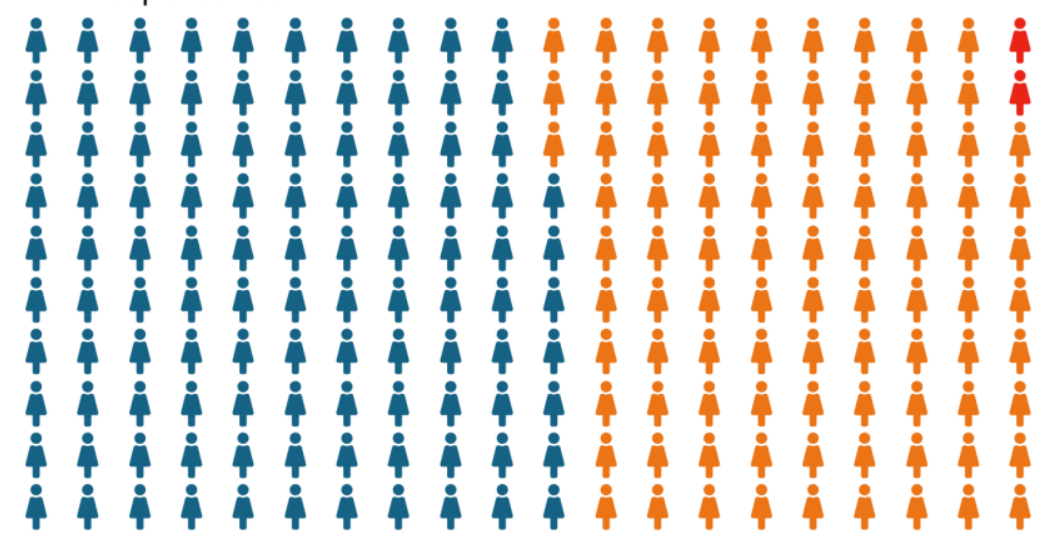

(B) IADL independence

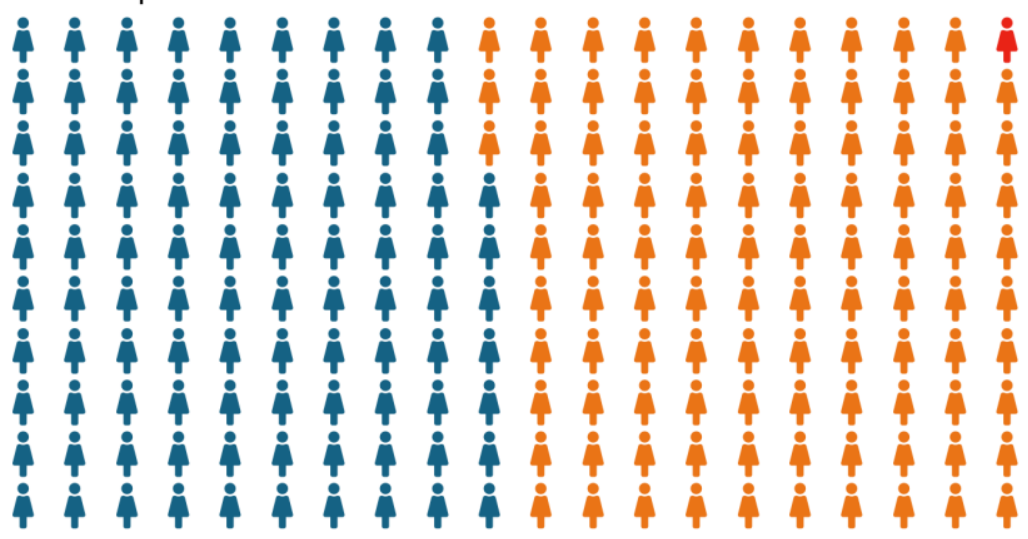

(C) Community dwelling
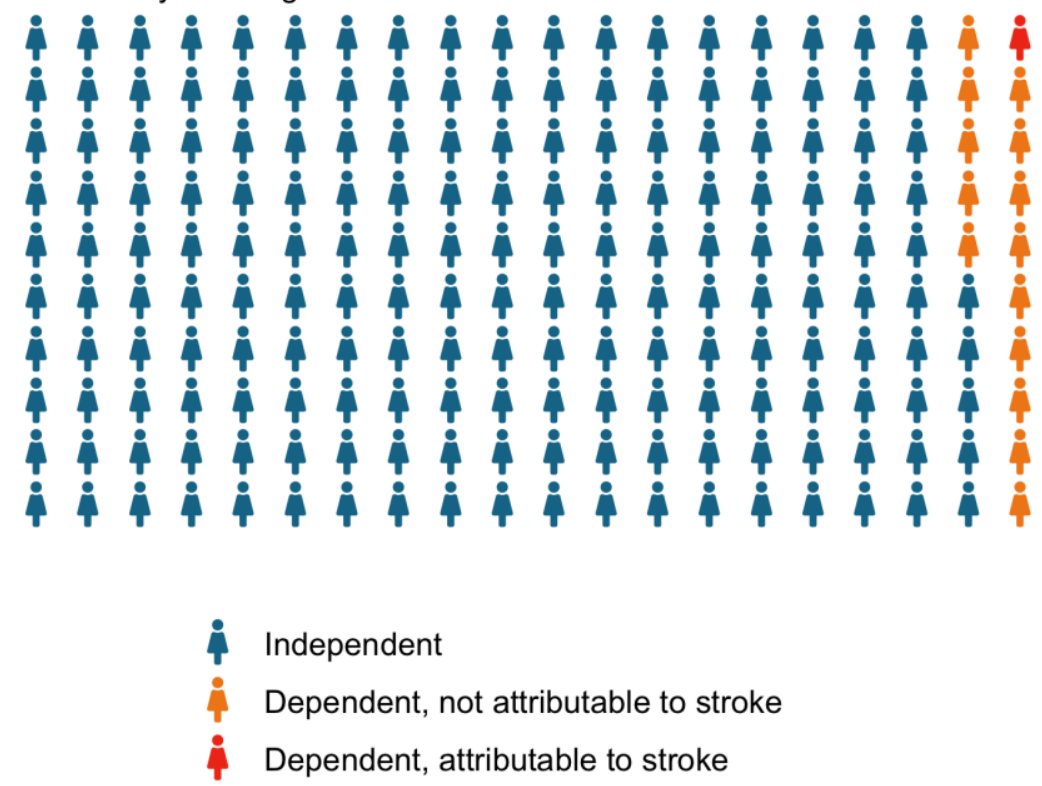

474

475 
medRxiv preprint doi: https://doi.org/10.1101/2020.11.05.20223297; this version posted November 6, 2020. The copyright holder for this preprint (which was not certified by peer review) is the author/funder, who has granted medRxiv a license to display the preprint in perpetuity. All rights reserved. No reuse allowed without permission.

476 Caption:

477 ADL - activity of daily living; IADL - instrumental activity of daily living

478

Each icon represents 0.5 person-years. Each panel contains 200 icons summing to 100 person-years. Values are all rounded to the nearest 0.5 . Exact values are presented in the text of the results.

To estimate the population burden of dependence attributable to strokes, we used the regression model results to calculate the likelihood of independence for each person based on their comorbidities and accounting for their survey sampling weight over seven years. Next, we used the same parameters to estimate the dependent-years for the same population assuming no strokes had occurred. The difference between the two measures of dependent-years represents the dependent-years attributable to stroke over 100 person-years (red icons, each representing 0.5 person-years). The blue icons represent independent 0.5 person-years. The yellow icons represent 0.5 dependent-years, not attributable to stroke. 
medRxiv preprint doi: https://doi.org/10.1101/2020.11.05.20223297; this version posted November 6, 2020. The copyright holder for this preprint (which was not certified by peer review) is the author/funder, who has granted medRxiv a license to display the preprint in perpetuity.

All rights reserved. No reuse allowed without permission.

499

500

501

502

503

504

505

506

507

508

509

510

511

\section{Appendix to "Long-term individual and population functional outcomes in older adults with atrial} fibrillation"

Anna L. Parks, MD (1), Sun Y. Jeon, MS PhD (2), Michael A. Steinman, MD (2), Alexander K. Smith, MD, MPH, MAS (2), Margaret C. Fang, MD, MPH (3), Sachin J. Shah, MD, MPH (3)

(1) Division of Hematology and Oncology, University of California, San Francisco, San Francisco, CA

(2) Division of Geriatrics, University of California, San Francisco, San Francisco, CA

(3) Division of Hospital Medicine, University of California, San Francisco, San Francisco, CA

\section{Contents}

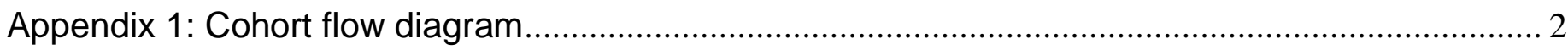

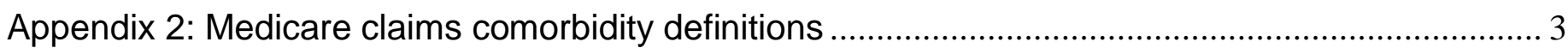

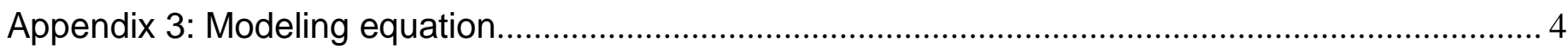

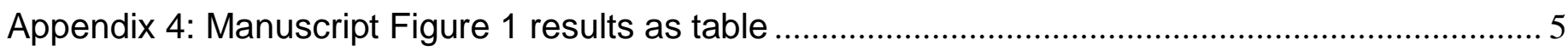

Appendix 5: Description of the method of recycled predictions to determine the contribution of strokes to population-level burden of disability.

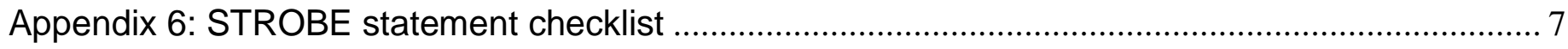

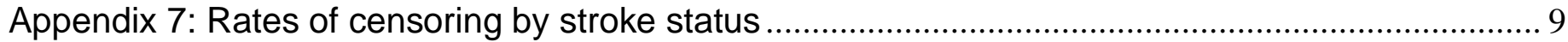


medRxiv preprint doi: https://doi.org/10.1101/2020.11.05.20223297; this version posted November 6, 2020. The copyright holder for this preprint (which was not certified by peer review) is the author/funder, who has granted medRxiv a license to display the preprint in perpetuity.

All rights reserved. No reuse allowed without permission.

\section{Appendix 1: Cohort flow diagram}

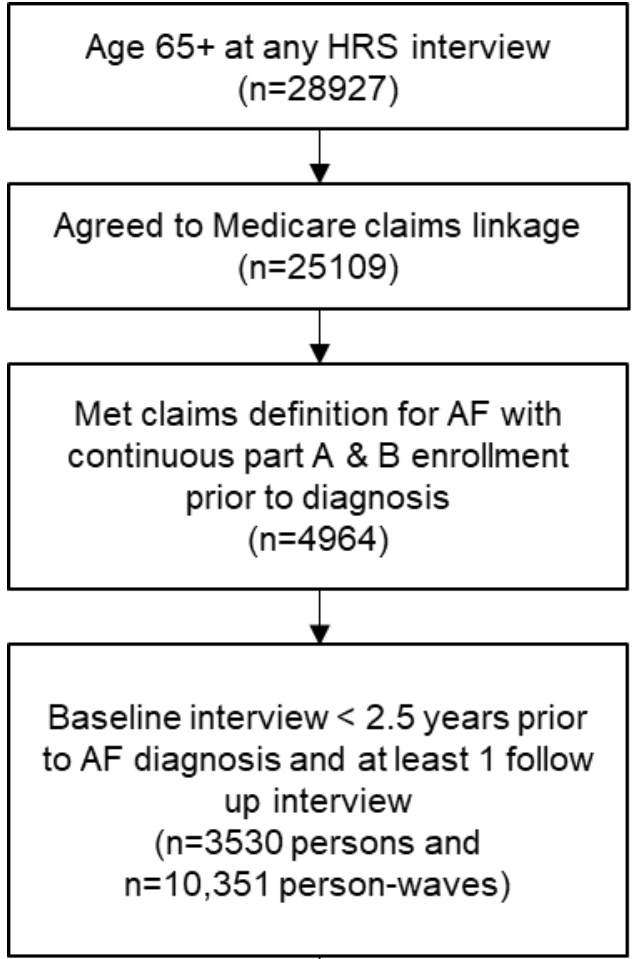

ADL analysis: 183 missing person-waves $(1.8 \%)$

- 159 missing next-of-kin interview on status prior to death, imputed as dependent prior to death $(1.5 \%)$

- 24 missing person-waves, excluded $(0.3 \%)$

IADL analysis: 372 missing person-waves (3.6\%)

- 159 missing next-of-kin interview on status prior to death, imputed as dependent prior to death (1.5\%)

- 213 missing person-waves, excluded $(2.1 \%)$

Nursing home analysis: 368 missing person-waves (3.6\%)

- 159 missing next-of-kin interview on status prior to death, not imputed, excluded $(1.5 \%)$

- 209 missing person-waves, excluded (2.0\%) 
medRxiv preprint doi: https://doi.org/10.1101/2020.11.05.20223297; this version posted November 6, 2020. The copyright holder for this preprint (which was not certified by peer review) is the author/funder, who has granted medRxiv a license to display the preprint in perpetuity.

All rights reserved. No reuse allowed without permission.

515 Appendix 2: Medicare claims comorbidity definitions

\begin{tabular}{|c|c|c|}
\hline Condition & $\begin{array}{l}\text { Criteria and } \\
\text { reference period }\end{array}$ & Valid ICD-9 Codes \\
\hline $\begin{array}{l}\text { Congestive } \\
\text { heart failure }\end{array}$ & $\begin{array}{l}\geq 1 \text { inpatient, HOP or } \\
\text { Carrier claim in the } \\
\text { last } 2 \text { years }\end{array}$ & $\begin{array}{l}\text { 398.91, 402.01, 402.11, 402.91, 404.01, 404.03, 404.11, 404.13, 404.91, } \\
\text { 404.93, 428.0, 428.1, 428.20, 428.21, 428.22, 428.23, 428.30, 428.31, 428.32, } \\
\text { 428.33, 428.40, 428.41, 428.42, 428.43, 428.9, 398.91, 402.01, 402.11, 402.91, } \\
\text { 404.01, 404.03, 404.11, 404.13, 404.91, 404.93, 428.0, 428.1, 428.20, 428.21, } \\
\text { 428.22, 428.23, 428.30, 428.31, 428.32, 428.33, 428.40, 428.41, 428.42, } \\
\text { 428.43, 428.9 (in any position) }\end{array}$ \\
\hline Hypertension & $\begin{array}{l}\geq 1 \text { inpatient, SNF, } \\
\text { HHA OR } 2 \text { HOP or } \\
\text { Carrier claim in the } \\
\text { last } 1 \text { year }\end{array}$ & $\begin{array}{l}362.11,401.0,401.1,401.9,402.00,402.01,402.10,402.11,402.90,402.91, \\
\text { 403.00, 403.01, 403.10, 403.11, 403.90, 403.91, 404.00, 404.01, 404.02, } \\
\text { 404.03, 404.10, 404.11, 404.12, 404.13, 404.90, 404.91, 404.92, 404.93, } \\
\text { 405.01, 405.09, 405.11, 405.19, 405.91, 405.99, 437.2 (in any position) }\end{array}$ \\
\hline Diabetes & $\begin{array}{l}\geq 1 \text { inpatient, SNF or } \\
\text { HHA OR } \geq 2 \mathrm{HOP} \text { or } \\
\text { Carrier claims in the } \\
\text { last } 2 \text { years }\end{array}$ & $\begin{array}{l}\text { 249.00, 249.01, 249.10, 249.11, 249.20, 249.21, 249.30, 249.31, 249.40, } \\
249.41,249.50,249.51,249.60,249.61,249.70,249.71,249.80,249.81, \\
249.90,249.91,250.00,250.01,250.02,250.03,250.10,250.11,250.12, \\
250.13,250.20,250.21,250.22,250.23,250.30,250.31,250.32,250.33, \\
250.40,250.41,250.42,250.43,250.50,250.51,250.52,250.53,250.60, \\
250.61,250.62,250.63,250.70,250.71,250.72,250.73,250.80,250.81, \\
250.82,250.83,250.90,250.91,250.92,250.93,357.2,362.01,362.02,362.03 \text {, } \\
362.04,362.05,362.06,366.41 \text { (in any position) }\end{array}$ \\
\hline Prior stroke & $\begin{array}{l}\geq 1 \text { inpatient OR } \\
2 \text { HOP or Carrier } \\
\text { claims in the last } 1 \\
\text { year }\end{array}$ & $\begin{array}{l}\text { DX 430, 431, 433.01, 433.11, 433.21, 433.31, 433.81, 433.91, 434.00, 434.01, } \\
434.10,434.11,434.90,434.91,435.0,435.1,435.3,435.8,435.9,436,997.02 \\
\text { (any DX on the claim); } \\
\text { EXCLUSION: If any of the qualifying claims have: } 800<=\text { DX Code }<=804.9, \\
850<=\text { DX Code }<=854.1 \text { in any DX position OR DX V57xx as the principal DX } \\
\text { Code, then EXCLUDE. }\end{array}$ \\
\hline $\begin{array}{l}\text { Vascular } \\
\text { disease: } \\
\text { Acute } \\
\text { myocardial } \\
\text { infarction } \\
\text { Ischemic } \\
\text { heart disease }\end{array}$ & $\begin{array}{l}\text { Acute myocardial } \\
\text { infarction: } \geq 1 \text { inpatient } \\
\text { claim in the last } 1 \\
\text { year } \\
\text { Ischemic heart } \\
\text { disease: } \geq 1 \text { inpatient, } \\
\text { SNF, HHA, HOP or } \\
\text { Carrier claim in last } 2 \\
\text { years }\end{array}$ & $\begin{array}{l}\text { Acute myocardial infarction: DX } 410.01,410.11,410.21,410.31,410.41, \\
410.51,410.61,410.71,410.81,410.91 \text { (ONLY first or second DX on the claim) } \\
\text { Ischemic heart disease: DX } 410.00,410.01,410.02,410.10,410.11,410.12 \text {, } \\
410.20,410.21,410.22,410.30,410.31,410.32,410.40,410.41,410.42, \\
410.50,410.51,410.52,410.60,410.61,410.62, \\
410.70,410.71,410.72,410.80,410.81,410.82,410.90,410.91,410.92,411.0 \text {, } \\
411.1,411.81,411.89,412,413.0,413.1,413.9,414.00,414.01,414.02, \\
414.03,414.04,414.05,414.06,414.07,414.12,414.2,414.3,414.4,414.8, \\
414.9 \text { (any DX on the claim) }\end{array}$ \\
\hline Cancer & $\begin{array}{l}\geq 1 \text { inpatient, SNF OR } \\
2 \text { HOP or Carrier } \\
\text { claims in last } 1 \text { year }\end{array}$ & $\begin{array}{l}\text { DX 153.0, 153.1, 153.2, 153.3, 153.4, 153.5, 153.6, 153.7, 153.8, 153.9, } \\
\text { 154.0,154.1, 230.3, 230.4, V10.05, V10.06, DX 174.0,174.1, 174.2, 174.3, } \\
\text { 174.4, 174.5, 174.6, 174.8, 174.9, 175.0, 175.9, 233.0, V10.3, DX 162.2, 162.3, } \\
\text { 162.4, 162.5, 162.8, 162.9, 231.2, V10.11, DX 185, 233.4, V10.46, DX C61, } \\
\text { D07.5, Z85.46 (any DX on the claim) }\end{array}$ \\
\hline
\end{tabular}


medRxiv preprint doi: https://doi.org/10.1101/2020.11.05.20223297; this version posted November 6, 2020. The copyright holder for this preprint (which was not certified by peer review) is the author/funder, who has granted medRxiv a license to display the preprint in perpetuity.

\section{Appendix 3: Modeling equation}

520

521

522

523

524

525

526

527

528

529

530

531

532

533

534

535

536

537

538

539

We fit the following model random effects model using a binary distribution and logit link to estimate the association of stroke and function (ADL, IADL, and independent living).

$$
\operatorname{logit}\left(E\left(Y_{i t}\right)\right)=\mu_{t}+\beta_{1} T_{t}+\beta_{2} S_{i t}+\beta_{3} T_{t} S_{i t}+\beta x_{i t}+\gamma z_{i}+\alpha_{i}
$$

Where:

$Y_{i t}=$ disability at time $t$ for individual $i$

$T=$ time since AF diagnosis

$S=$ an indicator representing incident stroke and all time periods following an incident stroke

$x=$ time-varying covariates (congestive heart failure, hypertension, diabetes, vascular disease, cancer, marital status, living alone, proxy respondent)

$z=$ time-invariant covariates (age at AF diagnosis, sex, history of stroke before AF diagnosis, race, ethnicity, educational attainment)

$\alpha_{i}=$ unobserved individual specific effect

From this model, we determined the baseline relative risk of the outcome $\beta_{1}$, the immediate change associated with stroke $\beta_{2}$, and the change in baseline relative risk following stroke $\beta_{3}$. These changes are graphically depicted below.

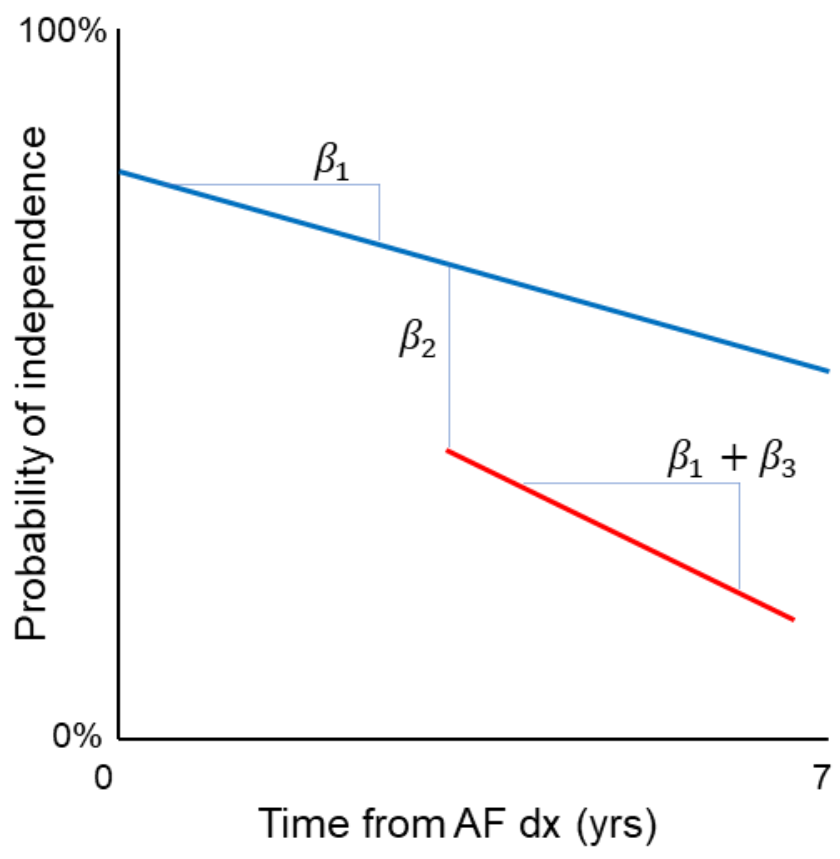


medRxiv preprint doi: https://doi.org/10.1101/2020.11.05.20223297; this version posted November 6, 2020. The copyright holder for this preprint (which was not certified by peer review) is the author/funder, who has granted medRxiv a license to display the preprint in perpetuity.

All rights reserved. No reuse allowed without permission.

\section{1}

542

543

544 545

\section{Appendix 4: Manuscript Figure 1 results as table}

Odds ratios and average marginal effects of stroke on ADL, IADL, nursing home residence adjusted for stroke risk

\begin{tabular}{|c|c|c|c|c|}
\hline Outcome & Parameter & $\begin{array}{r}\text { Unadjusted OR } \\
(95 \% \mathrm{Cl})\end{array}$ & $\begin{array}{r}\text { Adjusted OR } \\
(95 \% \mathrm{Cl}) \\
\end{array}$ & AME $(95 \% \mathrm{Cl})$ \\
\hline \multirow{3}{*}{$\begin{array}{l}\text { ADL } \\
\text { independence }\end{array}$} & $\begin{array}{l}\text { Pre-stroke rate of incident } \\
\text { disability } \beta_{1}\end{array}$ & $\begin{array}{r}0.67 \\
(0.64-0.69)\end{array}$ & $\begin{array}{r}0.92 \\
(0.89-0.95)\end{array}$ & $\begin{array}{r}-4.4 \% / y r \\
(-4.0 \text { to }-4.8 \% / y r)\end{array}$ \\
\hline & $\begin{array}{l}\text { Immediate change in } \\
\text { disability following stroke } \beta_{2}\end{array}$ & $\begin{array}{r}0.02 \\
(0.01-0.05)\end{array}$ & $\begin{array}{r}0.10 \\
(0.05-0.21)\end{array}$ & $\begin{array}{r}-31.9 \% \\
(-25.1 \text { to }-38.7 \%)\end{array}$ \\
\hline & $\begin{array}{l}\text { Change in rate of incident } \\
\text { disability post-stroke, relative } \\
\text { to pre-stroke rate } \beta_{3}\end{array}$ & $\begin{array}{r}1.12 \\
(1.01-1.25)\end{array}$ & $\begin{array}{r}1.02 \\
(0.93-1.12)\end{array}$ & -- \\
\hline \multirow{3}{*}{$\begin{array}{l}\text { IADL } \\
\text { independence }\end{array}$} & $\begin{array}{l}\text { Pre-stroke rate of incident } \\
\text { disability } \beta_{1}\end{array}$ & $\begin{array}{r}0.74 \\
(0.71-0.76)\end{array}$ & $\begin{array}{r}0.95 \\
(0.92-0.97)\end{array}$ & $\begin{array}{r}-3.9 \% \\
(-3.5 \text { to }-4.3 \%)\end{array}$ \\
\hline & $\begin{array}{l}\text { Immediate change in } \\
\text { disability following stroke } \beta_{2}\end{array}$ & $\begin{array}{r}0.04 \\
(0.02-0.10)\end{array}$ & $\begin{array}{r}0.16 \\
(0.08-0.32)\end{array}$ & $\begin{array}{r}-26.5 \% \\
(-19.8 \text { to }-33.3 \%)\end{array}$ \\
\hline & $\begin{array}{l}\text { Change in rate of incident } \\
\text { disability post-stroke, relative } \\
\text { to pre-stroke rate } \beta_{3}\end{array}$ & $\begin{array}{r}1.09 \\
(0.99-1.20)\end{array}$ & $\begin{array}{r}1.02 \\
(0.94-1.10)\end{array}$ & -- \\
\hline \multirow{3}{*}{$\begin{array}{l}\text { Continuous } \\
\text { independent } \\
\text { living }\end{array}$} & $\begin{array}{l}\text { Pre-stroke rate of incident } \\
\text { disability } \beta_{1}\end{array}$ & $\begin{array}{r}0.74 \\
(0.71-0.78)\end{array}$ & $\begin{array}{r}0.96 \\
(0.92-1.00)\end{array}$ & $\begin{array}{r}-1.2 \% \\
(-1.0 \text { to }-1.4 \%)\end{array}$ \\
\hline & $\begin{array}{l}\text { Immediate change in } \\
\text { disability following stroke } \beta_{2}\end{array}$ & $\begin{array}{r}0.07 \\
(0.03-0.18)\end{array}$ & $\begin{array}{r}0.24 \\
(0.11-0.52)\end{array}$ & $\begin{array}{r}-8.6 \% \\
(-3.7 \% \text { to }-13.5 \%)\end{array}$ \\
\hline & $\begin{array}{l}\text { Change in rate of incident } \\
\text { disability post-stroke, relative } \\
\text { to pre-stroke rate } \beta_{3}\end{array}$ & $\begin{array}{r}1.06 \\
(0.93-1.20)\end{array}$ & $\begin{array}{r}1.00 \\
(0.91-1.11)\end{array}$ & -- \\
\hline
\end{tabular}

546

547

548

549

550

551

552

553

554

\section{Legend}

OR - odds ratio, AME - average marginal effect

Unadjusted model does not include any time-varying or time invariant covariates. Adjusted model as noted in Appendix 4.

AME represents the predicted absolute change based on the population's comorbidities. AME for "change in rate of incident disability post stroke relative to pre-stroke rate" not estimated when the $95 \% \mathrm{Cl}$ for adjusted OR included 1. 
medRxiv preprint doi: https://doi.org/10.1101/2020.11.05.20223297; this version posted November 6, 2020. The copyright holder for this preprint (which was not certified by peer review) is the author/funder, who has granted medRxiv a license to display the preprint in perpetuity.

All rights reserved. No reuse allowed without permission.

555 Appendix 5: Description of the method of recycled predictions to determine the contribution of 556 strokes to population-level burden of disability

To estimate the contribution of strokes to the population disability burden, we determined the dependentyears had there been no strokes in the cohort.

First, we used the parameter estimates from the regression model (Appendix 4) to predict the probability of 562 independence for each individual over 7.4 years given their specific covariates, if they had a stroke and when it occurred, and survey sampling weight. We did not project beyond 7.4 years because less than $25 \%$ of the cohort contributed more than 7.4 years of follow up time. For the $7.4 \%$ who had a stroke, this corresponds to the area of $A+B$. For the $92.6 \%$ that did not have a stroke, this corresponds to the area of $A$ $+\mathrm{B}+\mathrm{C}$.

Next, among the $8.4 \%$ who had a stroke, we predicted the likelihood of independence assuming they did not have a stroke Area of $A+B+C$.

The difference between these two measures summed over the population represents the dependent-years attributable to stroke. We used this method to estimate the population burden for each of the three functional outcomes (ADL independence, IADL independence, community dwelling).

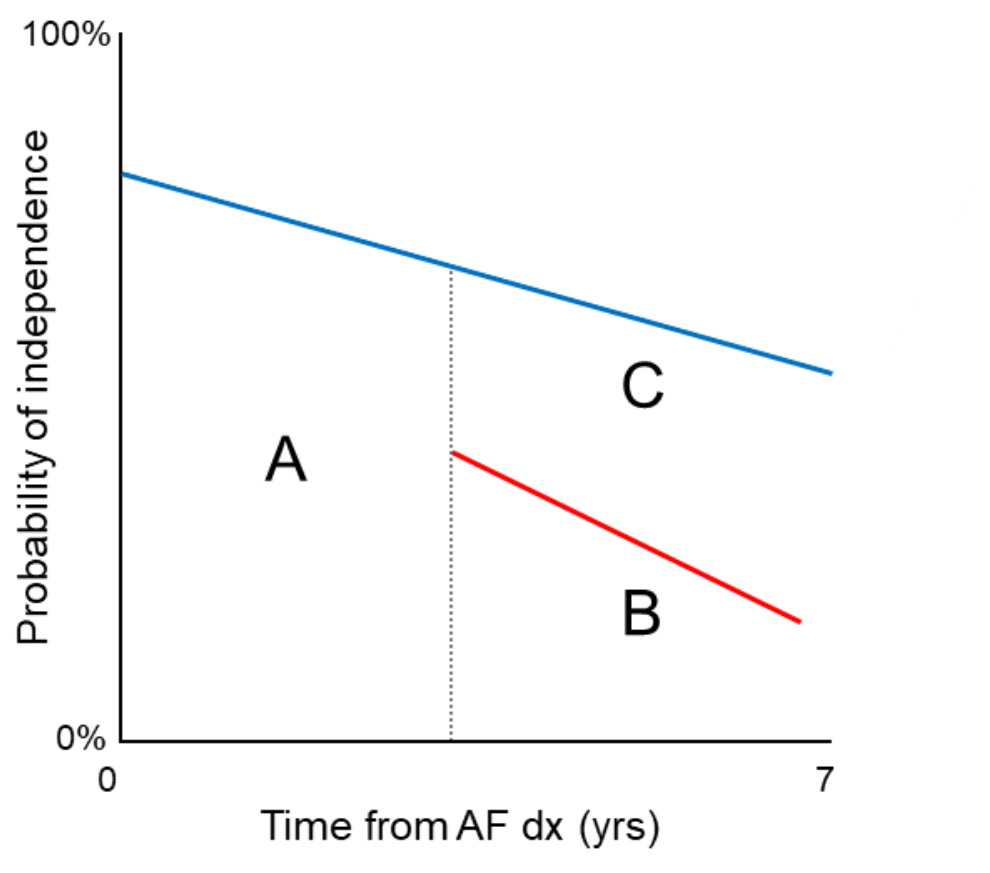


medRxiv preprint doi: https://doi.org/10.1101/2020.11.05.20223297; this version posted November 6, 2020. The copyright holder for this preprint (which was not certified by peer review) is the author/funder, who has granted medRxiv a license to display the preprint in perpetuity.

All rights reserved. No reuse allowed without permission.

\section{Appendix 6: STROBE statement checklist}

STROBE Statement—Checklist of items that should be included in reports of cohort studies

\begin{tabular}{|c|c|c|c|}
\hline & $\begin{array}{l}\text { Item } \\
\text { No }\end{array}$ & Recommendation & $\begin{array}{c}\text { Reported } \\
\text { on page }\end{array}$ \\
\hline \multirow[t]{2}{*}{ Title and abstract } & \multirow[t]{2}{*}{1} & $\begin{array}{l}\text { (a) Indicate the study's design with a commonly used term in the } \\
\text { title or the abstract }\end{array}$ & 1,2 \\
\hline & & $\begin{array}{l}\text { (b) Provide in the abstract an informative and balanced summary of } \\
\text { what was done and what was found }\end{array}$ & 2 \\
\hline \multicolumn{4}{|l|}{ Introduction } \\
\hline Background/rationale & 2 & $\begin{array}{l}\text { Explain the scientific background and rationale for the investigation } \\
\text { being reported }\end{array}$ & $3-4$ \\
\hline Objectives & 3 & State specific objectives, including any prespecified hypotheses & 4 \\
\hline \multicolumn{4}{|l|}{ Methods } \\
\hline Study design & 4 & Present key elements of study design early in the paper & $4-7$ \\
\hline Setting & 5 & $\begin{array}{l}\text { Describe the setting, locations, and relevant dates, including } \\
\text { periods of recruitment, exposure, follow-up, and data collection }\end{array}$ & 4 \\
\hline \multirow[t]{2}{*}{ Participants } & \multirow[t]{2}{*}{6} & $\begin{array}{l}\text { (a) Give the eligibility criteria, and the sources and methods of } \\
\text { selection of participants. Describe methods of follow-up }\end{array}$ & $4-5$ \\
\hline & & $\begin{array}{l}\text { (b) For matched studies, give matching criteria and number of } \\
\text { exposed and unexposed }\end{array}$ & $\mathrm{N} / \mathrm{A}$ \\
\hline Variables & 7 & $\begin{array}{l}\text { Clearly define all outcomes, exposures, predictors, potential } \\
\text { confounders, and effect modifiers. Give diagnostic criteria, if } \\
\text { applicable }\end{array}$ & $4-7$ \\
\hline $\begin{array}{l}\text { Data sources/ } \\
\text { measurement }\end{array}$ & $8^{*}$ & $\begin{array}{l}\text { For each variable of interest, give sources of data and details of } \\
\text { methods of assessment (measurement). Describe comparability of } \\
\text { assessment methods if there is more than one group }\end{array}$ & $4-7$ \\
\hline Bias & 9 & Describe any efforts to address potential sources of bias & $4-7,11$ \\
\hline Study size & 10 & Explain how the study size was arrived at & $\begin{array}{l}4-5, \\
\text { Appendix } 1\end{array}$ \\
\hline Quantitative variables & 11 & $\begin{array}{l}\text { Explain how quantitative variables were handled in the analyses. If } \\
\text { applicable, describe which groupings were chosen and why }\end{array}$ & $5-6$ \\
\hline \multirow[t]{5}{*}{ Statistical methods } & \multirow[t]{5}{*}{12} & $\begin{array}{l}\text { (a) Describe all statistical methods, including those used to control } \\
\text { for confounding }\end{array}$ & $6-7$ \\
\hline & & $\begin{array}{l}\text { (b) Describe any methods used to examine subgroups and } \\
\text { interactions }\end{array}$ & $6-7$ \\
\hline & & (c) Explain how missing data were addressed & $6-7$ \\
\hline & & (d) If applicable, explain how loss to follow-up was addressed & $6-7$ \\
\hline & & (e) Describe any sensitivity analyses & 11 \\
\hline
\end{tabular}

\section{Results}

Participants (a) Report numbers of individuals at each stage of study-eg numbers potentially eligible, examined for eligibility, confirmed eligible, included in the study, completing follow-up, and analysed

(b) Give reasons for non-participation at each stage

(c) Consider use of a flow diagram
Appendix 1

4,5 , Appendix 1 Appendix 1 
medRxiv preprint doi: https://doi.org/10.1101/2020.11.05.20223297; this version posted November 6, 2020. The copyright holder for this preprint (which was not certified by peer review) is the author/funder, who has granted medRxiv a license to display the preprint in perpetuity.

All rights reserved. No reuse allowed without permission.

Descriptive data $\quad 14^{*}$ (a) Give characteristics of study participants (eg demographic, clinical, social) and information on exposures and potential confounders

(b) Indicate number of participants with missing data for each $\quad$ Appendix 1 variable of interest

(c) Summarise follow-up time (eg, average and total amount) 7

\begin{tabular}{llll}
\hline Outcome data & $15^{\star}$ & Report numbers of outcome events or summary measures over & 8-9
\end{tabular}
time

\begin{tabular}{ll}
\hline Main results & $\begin{array}{l}\text { (a) Give unadjusted estimates and, if applicable, confounder- } \\
\text { adjusted estimates and their precision (eg, 95\% confidence } \\
\text { interval). Make clear which confounders were adjusted for and why } \\
\text { they were included }\end{array}$
\end{tabular}

(b) Report category boundaries when continuous variables were N/A categorized

(c) If relevant, consider translating estimates of relative risk into $\quad 8-10$ absolute risk for a meaningful time period

\begin{tabular}{|c|c|c|c|}
\hline Other analyses & 17 & $\begin{array}{l}\text { Report other analyses done-eg analyses of subgroups and } \\
\text { interactions, and sensitivity analyses }\end{array}$ & $\begin{array}{l}11, \\
\text { Appendix } 7\end{array}$ \\
\hline \multicolumn{4}{|l|}{ Discussion } \\
\hline Key results & 18 & Summarise key results with reference to study objectives & 9,10 \\
\hline Limitations & 19 & $\begin{array}{l}\text { Discuss limitations of the study, taking into account sources of } \\
\text { potential bias or imprecision. Discuss both direction and magnitude } \\
\text { of any potential bias }\end{array}$ & 11,12 \\
\hline Interpretation & 20 & $\begin{array}{l}\text { Give a cautious overall interpretation of results considering } \\
\text { objectives, limitations, multiplicity of analyses, results from similar } \\
\text { studies, and other relevant evidence }\end{array}$ & $10-12$ \\
\hline Generalisability & 21 & Discuss the generalisability (external validity) of the study results & $10-12$ \\
\hline \multicolumn{4}{|c|}{ Other information } \\
\hline Funding & 22 & $\begin{array}{l}\text { Give the source of funding and the role of the funders for the } \\
\text { present study and, if applicable, for the original study on which the } \\
\text { present article is based }\end{array}$ & 13 \\
\hline
\end{tabular}


medRxiv preprint doi: https://doi.org/10.1101/2020.11.05.20223297; this version posted November 6, 2020. The copyright holder for this preprint (which was not certified by peer review) is the author/funder, who has granted medRxiv a license to display the preprint in perpetuity.

All rights reserved. No reuse allowed without permission.

584

585

Appendix 7: Rates of censoring by stroke status

\begin{tabular}{|c|c|c|c|c|}
\hline & \multicolumn{2}{|c|}{ No stroke $(\mathrm{N}=3268)$} & \multicolumn{2}{|c|}{ Stroke (N=262) } \\
\hline Censored/year* & $\mathbf{N}$ & $\%$ & $\mathbf{N}$ & $\%$ \\
\hline $0-1$ & 735 & $22 \%$ & 23 & $9 \%$ \\
\hline $1-2$ & 348 & $11 \%$ & 30 & $11 \%$ \\
\hline $2-3$ & 353 & $11 \%$ & 32 & $12 \%$ \\
\hline $3-4$ & 276 & $8 \%$ & 16 & $6 \%$ \\
\hline $4-5$ & 285 & $9 \%$ & 22 & $8 \%$ \\
\hline $5-6$ & 220 & $7 \%$ & 19 & $7 \%$ \\
\hline $6-7$ & 190 & $6 \%$ & 22 & $8 \%$ \\
\hline $7-8$ & 156 & $5 \%$ & 20 & $8 \%$ \\
\hline $8-9$ & 127 & $4 \%$ & 11 & $4 \%$ \\
\hline $9-10$ & 128 & $4 \%$ & 14 & $5 \%$ \\
\hline $10-11$ & 94 & $3 \%$ & 10 & $4 \%$ \\
\hline $11-12$ & 74 & $2 \%$ & 9 & $3 \%$ \\
\hline $12-13$ & 73 & $2 \%$ & 9 & $3 \%$ \\
\hline 13-14 & 62 & $2 \%$ & 5 & $2 \%$ \\
\hline 14-15 & 43 & $1 \%$ & 9 & $3 \%$ \\
\hline $15-16$ & 39 & $1 \%$ & 3 & $1 \%$ \\
\hline $16-17$ & 25 & $1 \%$ & 0 & $0 \%$ \\
\hline $17-18$ & 17 & $1 \%$ & 1 & $0 \%$ \\
\hline 18-19 & 11 & $0 \%$ & 2 & $1 \%$ \\
\hline $19-20$ & 11 & $0 \%$ & 2 & $1 \%$ \\
\hline$>20$ & 1 & $0 \%$ & 3 & $1 \%$ \\
\hline Total & 3268 & $100 \%$ & 262 & $100 \%$ \\
\hline
\end{tabular}

587 Caption

588 *Participants were censored at the time of Medicare disenrollment, HRS drop out, or death, whichever came first.

To address the possible bias that those with the most severe or deadly strokes would be more likely to be censored, we performed a sensitivity analysis assessing rates of censoring by year according to stroke status. As demonstrated above, there was no differential loss to follow-up by stroke status. Moreover, rates of censoring were similar between stroke versus non-stroke on a year-by-year basis. 